\title{
IL-23R mutation is associated with ulcerative colitis: A systemic review and meta-analysis
}

\author{
Ling-Long Peng ${ }^{1}$, Ying Wang ${ }^{2}$, Feng-Ling Zhu ${ }^{1}$, Wang-Dong $\mathrm{Xu}^{3}{ }^{3}$, Xue-Lei $\mathrm{Ji}^{1}{ }^{1} \mathrm{Jing} \mathrm{Ni}^{4}$ \\ ${ }^{1}$ Department of Science and Education, The Second People's Hospital of Wuhu, Wuhu, Anhui 241000, China \\ ${ }^{2}$ Department of Environmental Health, Suzhou Municipal Center for Disease Prevention and Control, Suzhou, Jiangsu 215004, \\ China \\ ${ }^{3}$ Department of Rheumatology and Immunology, West China Hospital, Sichuan University, Chengdu, Sichuan 610041, China \\ ${ }^{4}$ The Teaching Centre for Preventive Medicine, School of Public Health, Anhui Medical University, Hefei, Anhui 230032, China \\ Correspondence to: Xue-Lei Ji, email: Jixueleiwh@163.com \\ Jing Ni, email: njahmu@126.com \\ Keywords: meta-analysis, ulcerative colitis, polymorphism, susceptibility, IL-23R
}

Received: June 15, $2016 \quad$ Accepted: November 12, $2016 \quad$ Published: November 25, 2016

\section{ABSTRACT}

Objectives: Since a genome-wide association study revealed that Interleukin-23 receptor (IL-23R) gene is a candidate gene for Ulcerative Colitis (UC), many studies have investigated the association between the IL-23R polymorphisms and UC. However, the results were controversial. The aim of the study was to determine whether the IL-23R polymorphisms confer susceptibility to UC.

Methods: A systematic literature search was carried out to identify all potentially relevant studies. Pooled odds ratios (ORs) with $95 \%$ confidence intervals (CIs) were used to estimate the strength of association.

Results: A total of 33 studies in 32 articles, including 10,527 UC cases and 15,142 healthy controls, were finally involved in the meta-analysis. Overall, a significant association was found between all UC cases and the rs11209026A allele $(\mathrm{OR}=0.665,95 \% \mathrm{CI}=0.604 \sim 0.733, P<0.001)$. Similarly, meta-analyses of the rs7517847, rs1004819, rs10889677, rs2201841, rs11209032, rs1495965, rs1343151 and rs11465804 polymorphisms also indicated significant association with all UC (all $P<0.05$ ). Stratification by ethnicity revealed that the rs11209026, rs7517847, rs10889677, rs2201841 andrs11465804 polymorphisms were associated with UC in the Caucasian group, but not in Asians, while the rs1004819 and rs11209032 polymorphisms were found to be related to UC for both Caucasian and Asian groups. However, subgroup analysis failed to unveil any association between the rs1495965 and rs1343151 polymorphisms and UC in Caucasians or Asians.

Conclusions: The meta-analysis suggests significant association between IL-23R polymorphisms and UC, especially in Caucasians.

\section{INTRODUCTION}

Ulcerative Colitis (UC) is a chronic relapsing and remitting intestinal inflammatory disorder that is confined to the mucosal and submucosal layers of rectum and colon, invading epithelial lining of the gut $[1,2]$. The etiology and pathogenesis of UC are still unclear, but the epidemiological data have suggested that genetic variation is a major risk factor for the evolution of UC $[3,4]$. Recently, a genome-wide association study
(GWAS) in north Indian identified three novel human leucocyte antigen (HLA)-independent UC risk loci from chromosome 6 [5]. Furthermore, a novel locus at 6q22.1 was found to be associated with UC in a south European population [6]. To date, approximately 100 UC susceptibility loci have identified via GWAS studies and immnochip data, and these loci are implicated in the pathphysiologic mechanisms of $\mathrm{UC}$, including microbe recognition, lymphocyte activation, cytokine signaling and intestinal epithelial defense [4-9]. Genetic 
studies provide clues on the immunopathogenesis for the disease, highlighting the role of immunity in the disease development of UC.

Interleukin-23 (IL-23) is a pro-inflammation cytokine secreted by activated macrophages and dendritic cells, which can influence the differentiation of native CD4+ $\mathrm{T}$ cells into $\mathrm{T}$ helper 17 subsets [10]. As a novel subset of Th cells, Th17 cells selectively secrete several pro-inflammatory cytokines, mainly IL-17, IL-6 and tumor necrosis factor (TNF- $\alpha)$ [11]. IL-23 binding to its receptor exerts profound effects through the Janus kinase (JAK)-signal transducer and activator of transcription (STAT) and NF- $\kappa \mathrm{B}$ signaling pathways $[12,13]$. Kenna et al. found that IL-23R was expressed at a significantly elevated level in the peripheral blood of ankylosing spondylitis (AS) patients, and the increased IL-23R levels were driven by large increases in the proportion of $\gamma / \delta$ $\mathrm{T}$ cells expressing IL-23R [14]. IL-17-secreting $\gamma / \delta \mathrm{T}$ cells, responding rapidly to IL-23 signals, can enhance autoimmunity by restraining the function of regulatory $\mathrm{T}$ cells by an IL-23-dependent mechanism [15]. An IL-23Rmediated altered response to IL-23 signals in $\gamma / \delta$ cells can lead to overproduction of IL-17, suggesting a potential mechanism that increasing IL-23R expression might play a role in the human autoimmune disease [14]. IL-23/IL-23R signaling has been confirmed as a key conductor of innate and adaptive inflammatory responses in the intestinal mucosa [17]. Studies on mice models have indicated that IL-23/IL-23R is essential for intestinal inflammation of $\mathrm{T}$ cell-dependent colitis [11, 17]. Furthermore, researches on human UC showed increased IL-23R expression levels in colon tissues [18]. A genome-wide association study by Duerr et al. firstly revealed that IL-23R was a potential candidate gene for UC susceptibility [19]. IL-23R gene is mapped to the chromosome 1 (1p31.3) [12]. In the last decade, polymorphisms in this locus have been identified, and then, multiple studies focus on the association between these polymorphisms and UC [20-51]. However, the results of previous studies in different populations are inconsistent. This discrepancy may be attributed to the sample size differences, inadequate statistical power, various racial and ethnic backgrounds, etc.

Meta-analysis is a statistical method of augmenting the effective sample size through merging data from single association studies, thus enhancing the statistical power of the analysis for the estimation of genetic effects [52]. Liu et al. have performed a meta-analysis to assess the association between the IL-23R gene polymorphisms and UC risk, but this meta-analysis only included sixteen studies [53], and more studies concerning the association between single nucleotide polymorphisms (SNPs) and UC risk have not been included. Thus, it seems necessary to perform a comprehensive meta-analysis including the current published studies to investigate the relationships between the IL-23R gene polymorphisms and susceptibility to UC.

\section{RESULTS}

\section{Study characteristics}

According to the inclusion and exclusion criteria, 32 published articles were included in the meta-analysis. Of the 32 articles, one included two cohorts [20], thus, each cohort was regarded as a separate study. Finally, a total of 33 studies in 32 articles were identified to examine the association between the IL-23R gene polymorphisms and susceptibility to UC, involving 10,527 patients with UC and 15,142 healthy controls. Overall, five studies were performed among Asians, and the other studies among Caucasians. The main characteristics of the 32 studies were summarized in Table 1.

\section{Evaluation of heterogeneity and publication bias}

Heterogeneity of the included studies regarding each polymorphism is presented in Table 2. Significant heterogeneity was found between the IL-23R rs10489629 polymorphism and $\mathrm{UC}$ in the overall and Caucasian populations $\left(\chi^{2}=14.14, \mathrm{I}^{2}=64.9 \%, P=0.015 ; \chi^{2}=\right.$ $14.14, \mathrm{I}^{2}=71.7 \%, P=0.007$, respectively). For the IL23R rs1343151 polymorphism, stratification analysis by ethnicity detected significant heterogeneity in the Caucasian group $\left(\chi^{2}=10.49, \mathrm{I}^{2}=52.3 \%, P=0.063\right)$. Sensitivity analysis was adopted to assess the stability of the results and explore potential sources of heterogeneity across studies. We used leave-one-out method by sequentially omitting each study to assess the influence of individual data on the obtained results. (Figure 1, Figure 2). After omitting Oliver et al. [24] and Daryani et al. [48], respectively, no significant heterogeneity was found. Therefore, the two studies might be the potential sources of heterogeneity across studies.

Evidence of publication bias was observed for the meta-analyses of the IL-23R rs2201841 and rs11209032 polymorphisms in the Caucasian population with a $P$ value for Egger's linear regression test: 0.026 and 0.044 . Then the "trim and fill" method was used to adjust for publication bias (Figure 3, Figure 4). Eventually, the adjusted OR calculation using the "trim and fill" technique remained significant $(\mathrm{OR}=1.176,95 \% \mathrm{CI}$ $=1.084 \sim 1.275 ;$ OR $=1.120,95 \%$ CI $=1.044 \sim 1.201$, respectively). The results did not materially altered by publication bias, indicating the robust stability of the current conclusions.

\section{Meta-analysis of the IL-23R gene polymorphisms in Ulcerative Colitis}

A summary of the meta-analysis of the association between the IL-23R gene polymorphisms and UC is presented in Table 2 and Supplementary Table S1. 
Table 1: Characteristics of the individual studies included in the meta-analysis

\begin{tabular}{|c|c|c|c|c|c|c|}
\hline $\begin{array}{l}\text { First author } \\
\text { (Year) }\end{array}$ & $\begin{array}{l}\text { Population } \\
\text { (Ethnicity) }\end{array}$ & $\mathbf{U C}$ & Control & Genotyping & $\begin{array}{l}\text { IL-23R polymorphisms } \\
\text { studied }\end{array}$ & HWE ( $P$-value) \\
\hline \multirow[t]{2}{*}{ Büning (2007) } & $\begin{array}{l}\text { Hungarian } \\
\text { (C) }\end{array}$ & 176 & 428 & PCR & rs11209026 & 0.457 \\
\hline & German $(\mathrm{C})$ & 118 & 200 & PCR & rs11209026 & 0.467 \\
\hline $\begin{array}{l}\text { Cummings } \\
\text { (2007) }\end{array}$ & $\begin{array}{c}\text { UK } \\
\text { Caucasian } \\
\text { (C) }\end{array}$ & 647 & 1149 & Sequencing & $\begin{array}{l}\text { rs1004819,rs7517847,rs10 } \\
\text { 489629,rs2201841,rs11209 } \\
\text { 026,rs1343151,rs11209032, } \\
\text { rs1495965 }\end{array}$ & NA \\
\hline Glas (2007) & German $(\mathrm{C})$ & 456 & 1381 & PCR & $\begin{array}{c}\text { rs } 1004819, \text { rs } 7517847, \text { rs } 10489 \\
629, \text { rs } 2201841, \text { rs } 11465804, r s \\
11209026, r s 1343151, r s 10889 \\
677, \text { rs } 11209032, r s 1495965\end{array}$ & NA \\
\hline $\begin{array}{l}\text { Limbergen } \\
(2007)\end{array}$ & British (C) & 86 & 342 & TaqMan & rs11209026 & 0.277 \\
\hline Oliver (2007) & Spanish (C) & 222 & 342 & TaqMan & $\begin{array}{c}\text { rs } 1004819, \text { rs } 7517847, \text { rs } 104 \\
89629, \text { rs } 11209026, \text { rs } 13431 \\
\text { 51,rs10889677,rs } 11209032, \\
\text { rs1495965 }\end{array}$ & $\begin{array}{c}0.346 ; 0.124 ; 0.023 ; 0.001 ; \\
0.734 ; 0.084 ; 0.087 ; 0.004\end{array}$ \\
\hline Roberts (2007) & $\begin{array}{c}\text { New } \\
\text { Zealander } \\
\text { (C) }\end{array}$ & 466 & 591 & TaqMan & rs11209026 & 0.776 \\
\hline $\begin{array}{l}\text { Tremelling } \\
(2007)\end{array}$ & $\begin{array}{c}\text { English } \\
\text { people }(\mathrm{C})\end{array}$ & 975 & 1345 & Sequencing & $\begin{array}{c}\text { rs } 1004819, \text { rs } 10489629, \text { rs } 11 \\
465804, \text {,s } 11209026, \text { rs } 13431 \\
\text { 51,rs10889677,rs11209032, } \\
\text { rs1495965 }\end{array}$ & NA \\
\hline $\begin{array}{l}\text { Lakatos } \\
(2008)\end{array}$ & $\begin{array}{l}\text { Hungarian } \\
\text { (A) }\end{array}$ & 149 & 149 & PCR & rs11209026 & NA \\
\hline $\begin{array}{l}\text { Lappalainen } \\
(2008)\end{array}$ & Finnish (C) & 459 & 292 & Sequencing & $\begin{array}{c}\text { rs1004819,rs } 10489629, \text { rs } 22 \\
01841, \text { rs } 11465804, \text { rs } 11209 \\
026, r s 1343151, \text { rs } 10889677, \\
\text { rs } 11209032\end{array}$ & NA \\
\hline Latiano (2008) & Italian (C) & 804 & 716 & TaqMan & rs7517847,rs11209026 & $0.459 ; 0.221$ \\
\hline Lu (2008) & Chinese (A) & 124 & 100 & PCR & rs11209026 & NA \\
\hline $\begin{array}{l}\text { Marquez } \\
(2008)\end{array}$ & Spanish (C) & 344 & 547 & TaqMan & rs7517847,rs11209026 & $0.710 ; 0.545$ \\
\hline $\begin{array}{l}\text { Okazaki } \\
(2008)\end{array}$ & Canadian (C) & 117 & 314 & TaqMan & $\begin{array}{c}\text { rs } 7517847, \text { rs } 2201841, \text { rs } 11209 \\
026, r s 10889677, \text { rs } 1495965\end{array}$ & $\begin{array}{c}0.910 ; 0.591 ; 0.725 ; 0.455 ; \\
0.181\end{array}$ \\
\hline $\begin{array}{l}\text { Venegas } \\
(2008)\end{array}$ & Chilean (C) & 62 & 59 & PCR-RFLP & rs11209026 & 0.840 \\
\hline $\begin{array}{l}\text { Weersma } \\
(2008)\end{array}$ & Dutch (C) & 207 & 893 & Sequencing & rs11209026 & 0.828 \\
\hline Chen (2008) & Chinese (A) & 40 & 50 & PCR & rs11209026 & NA \\
\hline $\begin{array}{l}\text { Weersma } \\
(2009)\end{array}$ & $\begin{array}{c}\text { Dutch- } \\
\text { Belgian (C) }\end{array}$ & 1442 & 1045 & Sequencing & rs11209026 & NA \\
\hline
\end{tabular}

(Continued) 


\begin{tabular}{|c|c|c|c|c|c|c|}
\hline $\begin{array}{l}\text { First author } \\
\text { (Year) }\end{array}$ & $\begin{array}{l}\text { Population } \\
\text { (Ethnicity) }\end{array}$ & $\mathbf{U C}$ & Control & Genotyping & $\begin{array}{l}\text { IL-23R polymorphisms } \\
\text { studied }\end{array}$ & HWE ( $P$-value) \\
\hline $\begin{array}{l}\text { Crotterill } \\
(2010)\end{array}$ & British (C) & 205 & 877 & Sequencing & rs11209026 & NA \\
\hline Lacher (2010) & German (C) & 132 & 253 & PCR-RFLP & rs11209026,rs7517847 & $0.789 ; 0.995$ \\
\hline $\begin{array}{l}\text { Mahurker } \\
(2010)\end{array}$ & Indian $(\mathrm{C})$ & 411 & 442 & Sequencing & rs11209026 & NA \\
\hline $\begin{array}{l}\text { Mitrovic } \\
(2010)\end{array}$ & $\begin{array}{l}\text { Slovenian } \\
\text { (C) }\end{array}$ & 136 & 345 & PCR-RFLP & rs7517847 & 0.056 \\
\hline $\begin{array}{l}\text { Sventoraityte } \\
(2010)\end{array}$ & $\begin{array}{l}\text { Lithuanian } \\
\text { (C) }\end{array}$ & 123 & 186 & TaqMan & rs11209026 & 0.002 \\
\hline Yang (2011) & Korean (A) & 654 & 601 & Sequencing & $\begin{array}{c}\text { rs1004819,rs2201841,rs10889 } \\
677, \text { rs } 11209032, \text { rs } 1495965\end{array}$ & $\begin{array}{c}0.378 ; 0.434 ; 0.367 ; 0.891 ; \\
0.810\end{array}$ \\
\hline Zhao (2011) & Chinese (A) & 135 & 134 & Sequencing & rs1343151,rs11209032 & $0.791 ; 0.668$ \\
\hline $\begin{array}{l}\text { Hayatbakhsh } \\
(2012)\end{array}$ & Iranian $(\mathrm{C})$ & 85 & 100 & PCR-RFLP & rs7517847,rs1004819 & $0.778 ; 0.879$ \\
\hline Safrany (2012) & $\begin{array}{l}\text { Hungarian } \\
\text { (C) }\end{array}$ & 282 & 253 & PCR-RFLP & $\begin{array}{c}\text { rs7517847,rs2201841,rs } 10889 \\
677, \text { rs } 11209032\end{array}$ & $0.081 ; 0.121 ; 0.024 ; 0.270$ \\
\hline Kanaan (2012) & $\begin{array}{l}\text { American } \\
\text { (C) }\end{array}$ & 276 & 435 & PCR & rs11465804 & NA \\
\hline $\mathrm{Yu}(2012)$ & Chinese (A) & 270 & 268 & Sequencing & $\begin{array}{c}\text { rs1004819,rs1495965,rs22 } \\
01841, \text { rs } 7517847, \text { rs } 104896 \\
\text { 29,rs10889677,rs1343151, } \\
\text { rs11209032 }\end{array}$ & NA \\
\hline $\begin{array}{l}\text { Ebrahimi } \\
\text { (2013) }\end{array}$ & Iranian $(\mathrm{C})$ & 67 & 78 & PCR & $\begin{array}{c}\text { rs1004819,rs2201841,rs10 } \\
889677, \text {,rs } 1495965, \text { rs } 75178 \\
\text { 47,rs10489629,rs11209026, } \\
\text { rs1343151 }\end{array}$ & $\begin{array}{l}0.650 ; 0.821 ; 0.821 ; 0.324 ; \\
0.699 ; 0.608 ; 0.724 ; 0.707\end{array}$ \\
\hline $\begin{array}{l}\text { Mihaljevic } \\
\text { (2013) }\end{array}$ & Croatian $(\mathrm{C})$ & 93 & 99 & PCR & rs11209026 & 0.449 \\
\hline $\begin{array}{l}\text { Skieceviciene } \\
\text { (2013) }\end{array}$ & $\begin{array}{l}\text { Lithuanian- } \\
\text { Latvian (C) }\end{array}$ & 444 & 1154 & TaqMan & $\begin{array}{c}\text { rs11209026,rs11465804,rs } 100 \\
4819, \text { rs } 10889677\end{array}$ & $0.137 ; 0.304 ; 0.373 ; 0.141$ \\
\hline Sarlos (2014) & $\begin{array}{l}\text { Hungarian } \\
\text { (C) }\end{array}$ & 320 & 316 & PCR-RFLP & rs1004819,rs2201841 & 0.545 \\
\hline
\end{tabular}

Abbreviations: UC: Ulcerative Colitis, C: Caucasian, A: Asian, NA: not available.

\section{IL-23R rs11209026, rs7517847, rs10889677, rs2201841 polymorphisms and UC}

Meta-analysis revealed that a significant association between the rs 11209026A allele and UC risk in the overall population $(\mathrm{OR}=0.665,95 \% \mathrm{CI}=0.604 \sim 0.733, P<$ 0.001 ; Figure 5 ). Furthermore, stratification by ethnicity indicated that the rs11209026A allele was significantly associated with UC risk in the Caucasian population (OR $=0.662,95 \% \mathrm{CI}=0.600 \sim 0.729, P<0.001 ;$ Figure 5), but not in the Asian population. Meta-analyses of the rs7517847, rs10889677, rs2201841 polymorphisms also showed the same pattern as for the results of rs 11209026 . All these polymorphisms were found to be related to UC susceptibility in Caucasians, but not in Asians (Table 2).

\section{IL-23R rs1004819, rs11209032 polymorphisms and $\mathrm{UC}$}

Overall, meta-analysis of the IL-23R rs1004819 and rs11209032 polymorphisms showed significant association between UC and the minor alleles in all study 
Table 2: Meta-analysis of IL-23R polymorphisms in UC

\begin{tabular}{|c|c|c|c|c|c|c|c|c|c|c|c|c|}
\hline \multirow[t]{2}{*}{ Polymorphisms } & \multirow[t]{2}{*}{ Population } & \multirow{2}{*}{$\begin{array}{l}\text { NO. of } \\
\text { studies }\end{array}$} & \multicolumn{2}{|c|}{ Sample size } & \multicolumn{4}{|c|}{ Test of association } & \multicolumn{3}{|c|}{$\begin{array}{c}\text { Test of } \\
\text { heterogeneity }\end{array}$} & \multirow{2}{*}{$\begin{array}{l}\text { Egger's } \\
\text { test }(P)\end{array}$} \\
\hline & & & Case & Control & OR $(95 \% \mathrm{CI})$ & $\mathbf{Z}$ & $P$ & Model & $\chi^{2}$ & $P$ & $I^{2}(\%)$ & \\
\hline rs11209026 & Overall & 25 & 8243 & 12899 & $\begin{array}{c}0.665 \\
(0.604 \sim 0.733)\end{array}$ & 8.25 & $<0.001$ & $\mathrm{~F}$ & 17.15 & 0.876 & 0.0 & 0.187 \\
\hline \multirow[t]{2}{*}{$\begin{array}{l}\text { A versus } G \\
\text { allele }\end{array}$} & Caucasian & 23 & 8141 & 12799 & $\begin{array}{c}0.662 \\
(0.600 \sim 0.729)\end{array}$ & 8.30 & $<0.001$ & $\mathrm{~F}$ & 16.15 & 0.849 & 0.0 & 0.092 \\
\hline & Asian & 2 & 102 & 100 & $\begin{array}{c}1.004 \\
(0.452 \sim 2.232)\end{array}$ & 0.01 & 0.992 & $\mathrm{~F}$ & 0.03 & 0.864 & 0.0 & NA \\
\hline rs7517847 & Overall & 12 & 3589 & 5536 & $\begin{array}{c}0.818 \\
(0.768 \sim 0.871)\end{array}$ & 6.31 & $<0.001$ & $\mathrm{~F}$ & 5.78 & 0.887 & 0.0 & 0.535 \\
\hline \multirow[t]{2}{*}{$\begin{array}{l}\text { G versus } T \\
\text { allele }\end{array}$} & Caucasian & 11 & 3319 & 5268 & $\begin{array}{c}0.817 \\
(0.766 \sim 0.871)\end{array}$ & 6.14 & $<0.001$ & $\mathrm{~F}$ & 5.76 & 0.835 & 0.0 & 0.570 \\
\hline & Asian & 1 & 270 & 268 & $\begin{array}{c}0.833 \\
(0.652 \sim 1.063)\end{array}$ & 1.47 & 0.142 & NA & NA & NA & NA & NA \\
\hline rs1004819 & Overall & 11 & 4555 & 6994 & $\begin{array}{c}1.196 \\
(1.129 \sim 1.267)\end{array}$ & 6.09 & $<0.001$ & $\mathrm{~F}$ & 6.98 & 0.727 & 0.0 & 0.264 \\
\hline \multirow[t]{2}{*}{$\begin{array}{l}\text { T versus } \mathrm{C} \\
\text { allele }\end{array}$} & Caucasian & 9 & 3677 & 6131 & $\begin{array}{c}1.208 \\
(1.133 \sim 1.287)\end{array}$ & 5.80 & $<0.001$ & $\mathrm{~F}$ & 6.15 & 0.631 & 0.0 & 0.216 \\
\hline & Asian & 2 & 878 & 863 & $\begin{array}{c}1.146 \\
(1.002 \sim 1.311)\end{array}$ & 1.98 & 0.047 & $\mathrm{~F}$ & 0.35 & 0.553 & 0.0 & NA \\
\hline rs 10889677 & Overall & 10 & 3948 & 5998 & $\begin{array}{c}1.201 \\
(1.127 \sim 1.280)\end{array}$ & 5.64 & $<0.001$ & $\mathrm{~F}$ & 7.24 & 0.612 & 0.0 & 0.461 \\
\hline \multirow[t]{2}{*}{$\begin{array}{l}\text { A versus } \mathrm{C} \\
\text { allele }\end{array}$} & Caucasian & 8 & 3025 & 5134 & $\begin{array}{c}1.217 \\
(1.134 \sim 1.306)\end{array}$ & 5.47 & $<0.001$ & $\mathrm{~F}$ & 5.99 & 0.541 & 0.0 & 0.539 \\
\hline & Asian & 2 & 923 & 864 & $\begin{array}{c}1.132 \\
(0.976 \sim 1.313)\end{array}$ & 1.64 & 0.101 & $\mathrm{~F}$ & 0.49 & 0.483 & 0.0 & NA \\
\hline rs2201841 & Overall & 9 & 3265 & 4638 & $\begin{array}{c}1.163 \\
(1.083 \sim 1.249)\end{array}$ & 4.15 & $<0.001$ & $\mathrm{~F}$ & 6.09 & 0.638 & 0.0 & 0.090 \\
\hline \multirow[t]{3}{*}{$\begin{array}{l}\mathrm{C} \text { versus } \mathrm{T} \\
\text { allele }\end{array}$} & Caucasian & 7 & 2356 & 3783 & $\begin{array}{c}1.175 \\
(1.083 \sim 1.274)\end{array}$ & 3.87 & $<0.001$ & $\mathrm{~F}$ & 5.08 & 0.533 & 0.0 & 0.026 \\
\hline & & $7^{\mathrm{a}}$ & NA & NA & $\begin{array}{c}1.176 \\
(1.084 \sim 1.275)\end{array}$ & 3.92 & $<0.001$ & $\mathrm{~F}$ & NA & NA & NA & NA \\
\hline & Asian & 2 & 909 & 855 & $\begin{array}{c}1.126 \\
(0.971 \sim 1.307)\end{array}$ & 1.57 & 0.117 & $\mathrm{~F}$ & 0.76 & 0.382 & 0.0 & NA \\
\hline rs11209032 & Overall & 9 & 4073 & 5752 & $\begin{array}{c}1.127 \\
(1.060 \sim 1.197)\end{array}$ & 3.85 & $<0.001$ & $\mathrm{~F}$ & 5.27 & 0.729 & 0.0 & 0.249 \\
\hline \multirow[t]{3}{*}{$\begin{array}{l}\text { A versus } G \\
\text { allele }\end{array}$} & Caucasian & 6 & 3041 & 4762 & $\begin{array}{c}1.116 \\
(1.041 \sim 1.197)\end{array}$ & 3.10 & 0.002 & $\mathrm{~F}$ & 4.82 & 0.438 & 0.0 & 0.044 \\
\hline & & $6^{\mathrm{a}}$ & NA & NA & $\begin{array}{c}1.120 \\
(1.044 \sim 1.201)\end{array}$ & 3.12 & 0.002 & $\mathrm{~F}$ & NA & NA & NA & NA \\
\hline & Asian & 3 & 1032 & 990 & $\begin{array}{c}1.160 \\
(1.025 \sim 1.312)\end{array}$ & 2.35 & 0.019 & $\mathrm{~F}$ & 0.16 & 0.922 & 0.0 & 0.312 \\
\hline rs1495965 & Overall & 8 & 3415 & 5473 & $\begin{array}{c}1.073 \\
(1.008 \sim 1.141)\end{array}$ & 2.22 & 0.026 & $\mathrm{~F}$ & 7.19 & 0.409 & 2.6 & 0.392 \\
\hline $\begin{array}{l}\text { G versus A } \\
\text { allele }\end{array}$ & Caucasian & 6 & 2492 & 4609 & $\begin{array}{c}1.072 \\
(0.999 \sim 1.149)\end{array}$ & 1.94 & 0.053 & $\mathrm{~F}$ & 7.17 & 0.208 & 30.3 & 0.482 \\
\hline
\end{tabular}

(Continued) 


\begin{tabular}{|c|c|c|c|c|c|c|c|c|c|c|c|c|}
\hline \multirow{2}{*}{ Polymorphisms } & \multirow{2}{*}{ Population } & \multirow{2}{*}{$\begin{array}{l}\text { NO. of } \\
\text { studies }\end{array}$} & \multicolumn{2}{|c|}{ Sample size } & \multicolumn{4}{|c|}{ Test of association } & \multicolumn{3}{|c|}{$\begin{array}{c}\text { Test of } \\
\text { heterogeneity }\end{array}$} & \multirow{2}{*}{$\begin{array}{l}\text { Egger' } \\
\text { test }(P)\end{array}$} \\
\hline & & & $\overline{\text { Case }}$ & Control & OR $(95 \%$ CI $)$ & $\mathbf{Z}$ & $P$ & Model & $\chi^{2}$ & $P$ & $\overline{I^{2}(\%)}$ & \\
\hline & Asian & 2 & 923 & 864 & $\begin{array}{c}1.076 \\
(0.944 \sim 1.227)\end{array}$ & 1.09 & 0.274 & $\mathrm{~F}$ & 0.02 & 0.892 & 0.0 & NA \\
\hline rs 1343151 & Overall & 8 & 3241 & 4989 & $\begin{array}{c}0.900 \\
(0.836 \sim 0.969)\end{array}$ & 2.80 & 0.005 & $\mathrm{~F}$ & 10.57 & 0.158 & 33.8 & 0.213 \\
\hline \multirow[t]{2}{*}{$\begin{array}{l}\mathrm{T} \text { versus } \mathrm{C} \\
\text { allele }\end{array}$} & Caucasian & 6 & 2836 & 4587 & $\begin{array}{c}0.916 \\
(0.812 \sim 1.032)\end{array}$ & 1.45 & 0.148 & $\mathrm{R}$ & 10.49 & 0.063 & 52.3 & 0.142 \\
\hline & Asian & 2 & 405 & 402 & $\begin{array}{c}0.992 \\
(0.513 \sim 1.922)\end{array}$ & 0.02 & 0.982 & $\mathrm{~F}$ & 0.0 & 1.000 & 0.0 & NA \\
\hline rs10489629 & Overall & 6 & 3029 & 4777 & $\begin{array}{c}0.944 \\
(0.837 \sim 1.065)\end{array}$ & 0.93 & 0.350 & $\mathrm{R}$ & 14.14 & 0.015 & 64.9 & 0.259 \\
\hline \multirow[t]{2}{*}{$\begin{array}{l}\mathrm{G} \text { versus A } \\
\text { allele }\end{array}$} & Caucasian & 5 & 2759 & 4509 & $\begin{array}{c}0.951 \\
(0.829 \sim 1.090)\end{array}$ & 0.72 & 0.470 & $\mathrm{R}$ & 14.14 & 0.007 & 71.7 & 0.179 \\
\hline & Asian & 1 & 270 & 268 & $\begin{array}{c}0.914 \\
(0.692 \sim 1.206)\end{array}$ & 0.64 & 0.525 & NA & NA & NA & NA & NA \\
\hline rs11465804 & Overall & 5 & 2530 & 4428 & $\begin{array}{c}0.760 \\
(0.639 \sim 0.904)\end{array}$ & 3.10 & 0.002 & $\mathrm{~F}$ & 2.39 & 0.664 & 0.0 & 0.747 \\
\hline $\begin{array}{l}\mathrm{G} \text { versus } \mathrm{T} \\
\text { allele }\end{array}$ & Caucasian & 5 & 2530 & 4428 & $\begin{array}{c}0.760 \\
(0.639 \sim 0.904)\end{array}$ & 3.10 & 0.002 & $\mathrm{~F}$ & 2.39 & 0.664 & 0.0 & 0.747 \\
\hline
\end{tabular}

Abbreviations: UC: Ulcerative Colitis, F: fixed effects model, R: random effects model, NA: not available.

aAdjusted using the "trim and fill" method.

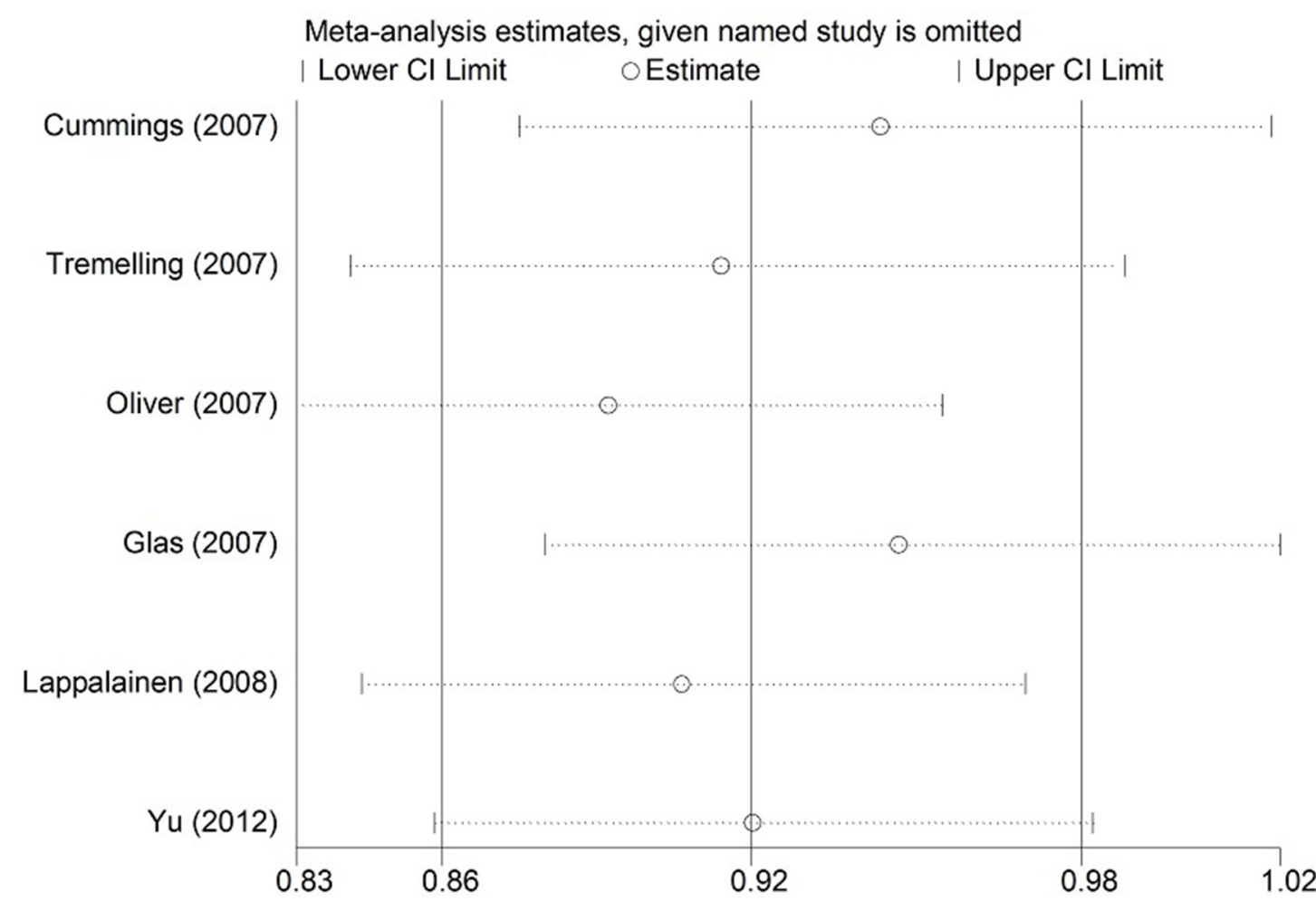

Figure 1: Sensitivity analysis of the summary odds ratio (OR) coefficients on the association between the IL-23R rs10489629 polymorphism and UC under allele contrast. 


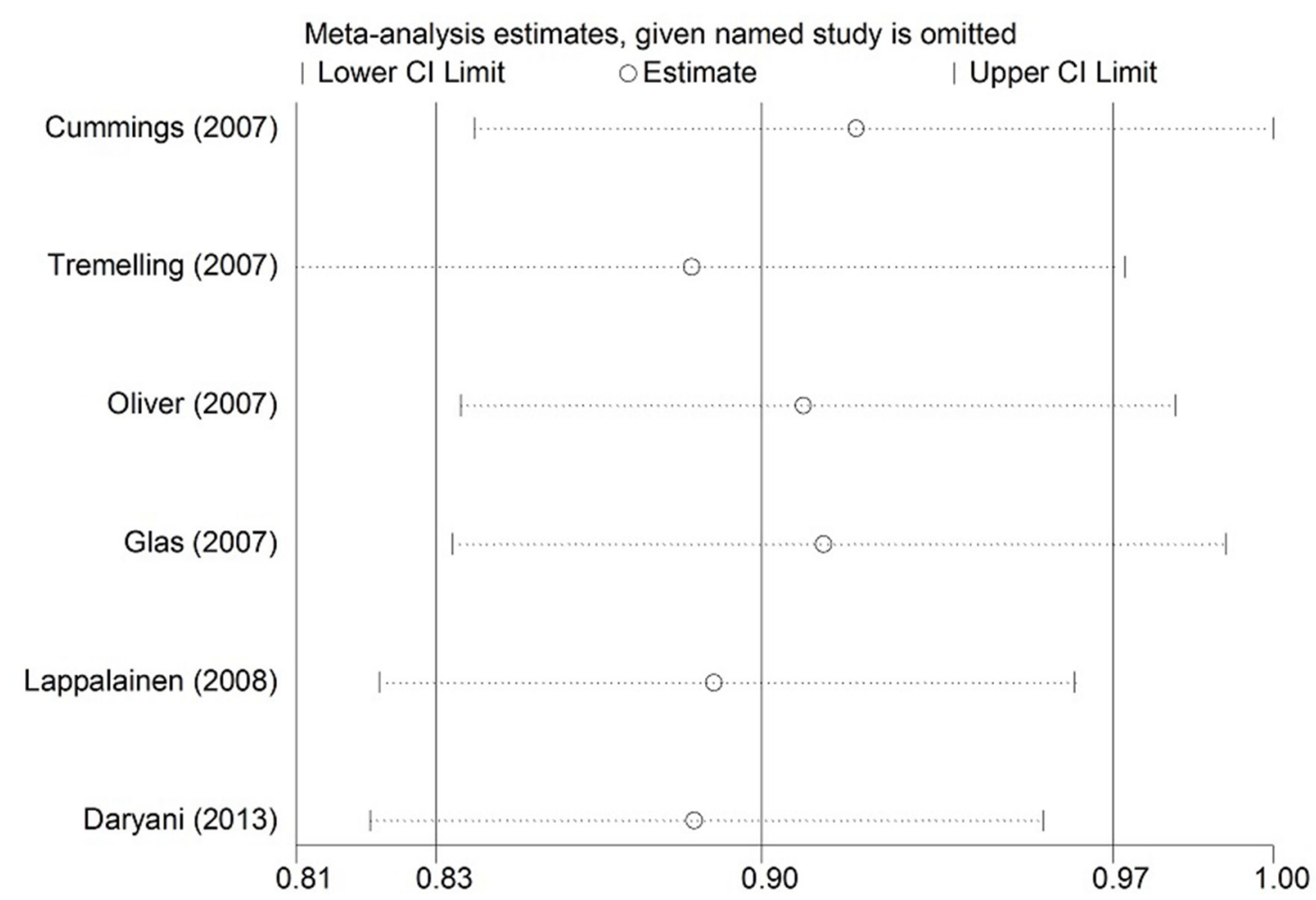

Figure 2: Sensitivity analysis of the summary odds ratio (OR) coefficients on the association between the IL-23R rs1343151 polymorphism and UC under allele contrast.

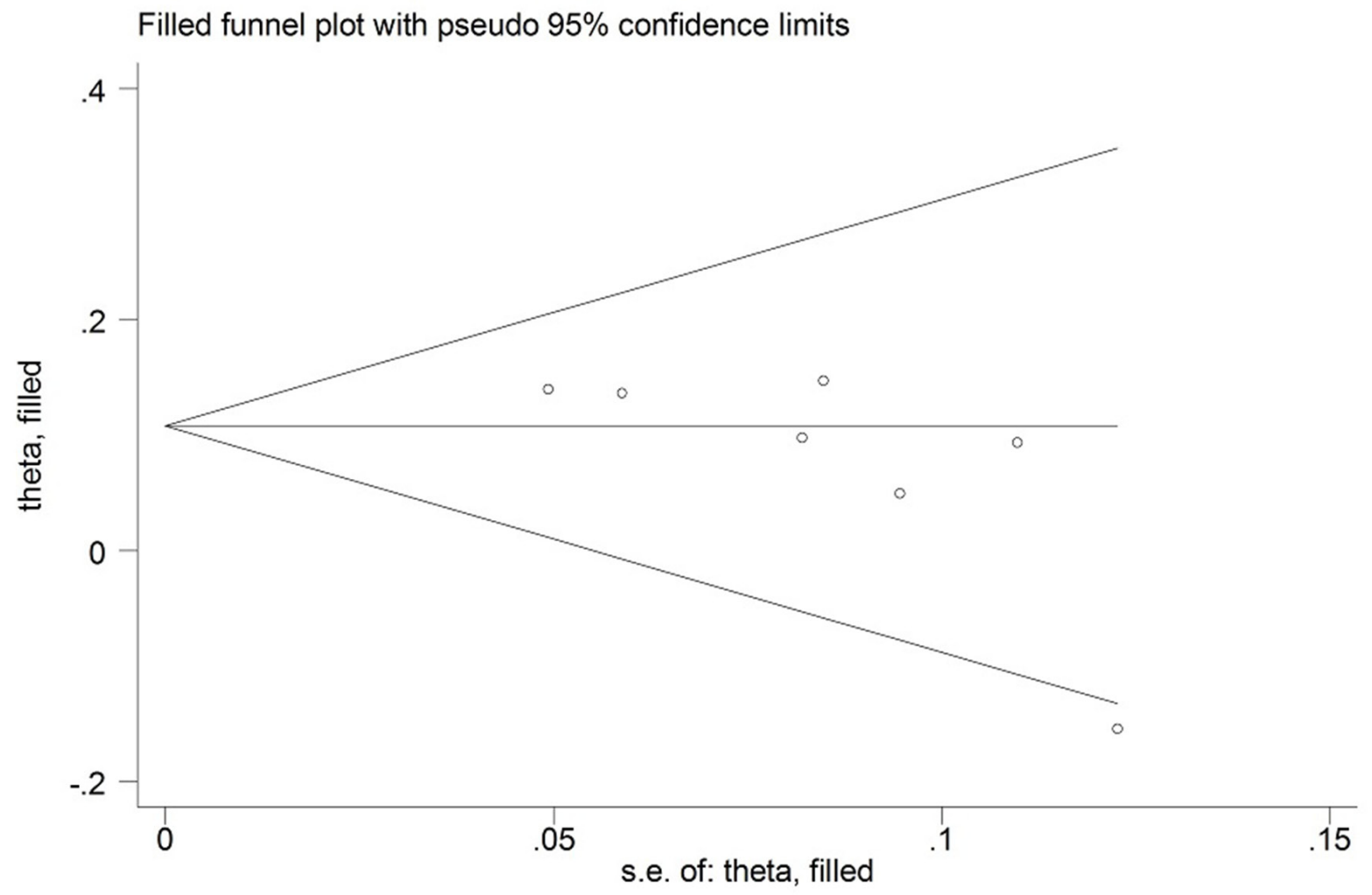

Figure 3: Funnel plots for meta-analysis of association between the IL-23R rs2201841 polymorphism and UC in the Caucasian population using the "trim and fill" technique. 
subjects $(\mathrm{OR}=1.196,95 \% \mathrm{CI}=1.129 \sim 1.267, P<0.001$; $\mathrm{OR}=1.127,95 \% \mathrm{CI}=1.060 \sim 1.197, P<0.001$ ) (Table 2). Meanwhile, significant associations were also detected between these two polymorphisms and UC susceptibility in both Caucasians and Asians through the subgroup analysis stratified by ethnicity.

\section{IL-23R rs1495965, rs1343151 polymorphisms and $\mathrm{UC}$}

Meta-analysis showed significant association between the minor alleles of the rs1495965 and rs1343151 polymorphisms and the risk of UC in the overall population $(\mathrm{OR}=1.073,95 \% \mathrm{CI}=1.008 \sim 1.141$, $P<0.001 ;$ OR $=0.900,95 \%$ CI $=0.836 \sim 0.969, P=$ 0.005 , respectively). However, ethnicity-specific analysis failed to identify any associations between the two polymorphisms and UC risk in neither Caucasian nor Asian subjects.

\section{IL-23R rs10489629, rs11465804 polymorphism and $\mathrm{UC}$}

No association was found between UC and the IL-23R rs10489629 polymorphism by meta-analyses (Table 2). For the IL-23R rs11465084 polymorphism, a significant association was observed in the $G$ versus $T$ allele in the Caucasian origin $(\mathrm{OR}=0.760,95 \% \mathrm{CI}=$ $0.639 \sim 0.904, P=0.002)$. However, there is no such study performed in the Asian group.

\section{DISCUSSION}

UC is characterized by chronic intestinal inflammation as a result of an aberrant immune response. Considerable progress has been made in understanding the pathogenesis of UC. An inappropriate muscosal immune response to commensal bacterial flora induced by the interaction of environmental and genetic factors has been proposed [54]. Amounts of genetic association studies have identified many genes including nucleotide oligomerization domain 2 (NOD2), autophagy genes, STAT3, Cytotoxic T lymphocyte associated antigen-4 (CTLA-4) and genes whose products function in the IL-23/Th17 pathway, which play an important role in perpetuating the abnormal inflammatory response, have been considered as candidate genes in disease initiation of $\mathrm{UC}[3,29,32]$. Genetic polymorphisms of the IL$23 \mathrm{R}$ gene have been investigated in many autoimmune diseases, and researches have showed that IL-23R gene is associated with the etiology of AS, psoriasis, rheumatoid arthritis (RA), and multiple sclerosis, inflammation bowel disease (IBD) [19, 55]. Since a genome wide association study by Duerr et al. firstly showed strong correlation of

Filled funnel plot with pseudo $95 \%$ confidence limits

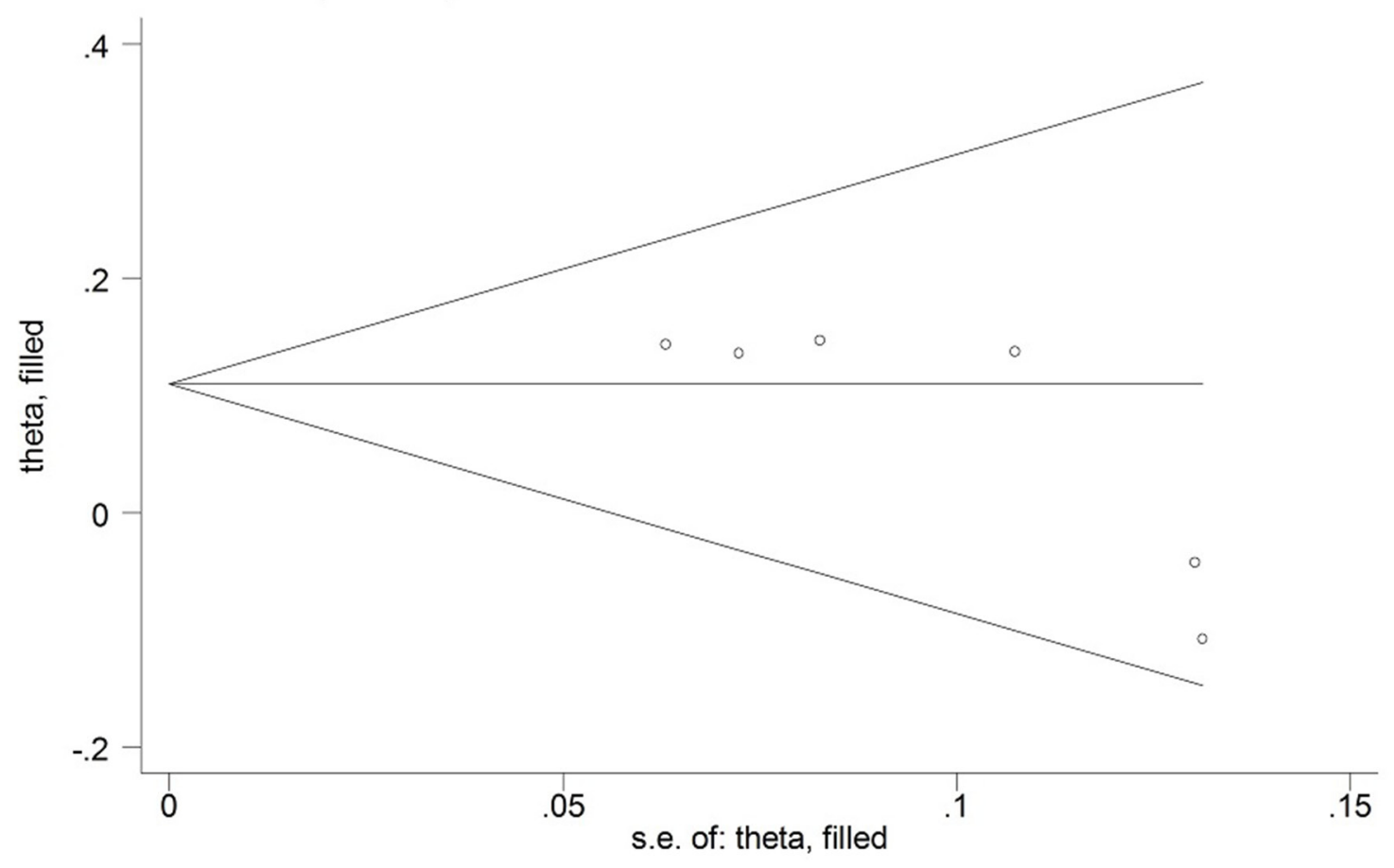

Figure 4: Funnel plots for meta-analysis of association between the IL-23R rs11209032 polymorphism and UC in the Caucasian population using the "trim and fill" technique. 
the IL-23R polymorphisms and UC, numerous studies have been carried out to detect the association between IL-23R polymorphisms and UC [19]. However, different research teams obtained contradictory results in different populations. For example, a study from Hayatbakhsh et al. indicated no association between the IL-23R gene polymorphisms rs7517847 and rs1004819 and the susceptibility of UC in an Iranian population [17]. Similarly, a study in a Finnish population demonstrated that the IL-23R polymorphisms (rs1004819, rs10489629, rs2201841, rs11465804, rs11209026, rs1343151, rs10889677, rs11209032) were not related to UC [28], while a study in England and Scotland revealed an association between the IL-23R polymorphisms (rs1004819, rs11209026, rs10889677, rs11209032) and UC [26]. Therefore, to better comprehend the relationship of the IL-23R gene polymorphisms and UC, we summarize the inconsistent results by meta-analysis to overcome small sample size problems of individual studies and enhance the statistical power and draw a more comprehensive and reliable conclusion.

The meta-analysis was conducted to discuss the association of ten polymorphisms in the IL-23R gene (rs11209026, rs7517847, rs1004819, rs10889677, rs2201841, rs11209032, rs1495965, rs1343151, rs10489629, rs11465804) and UC. Overall, IL-23R gene

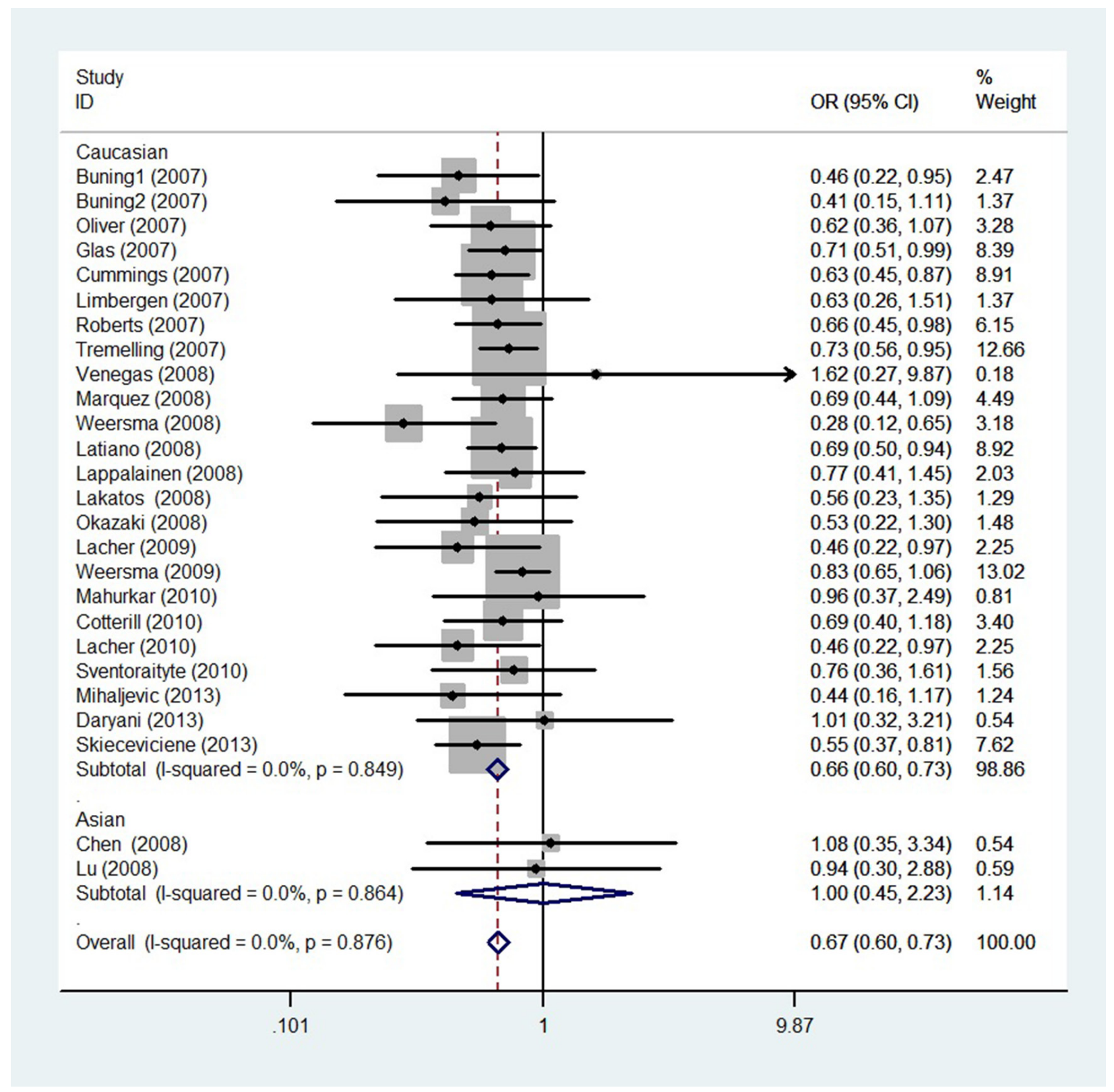

Figure 5: Odds ratios and $95 \%$ confidence intervals for individual studies and pooled data for the association between the A versus $G$ allele of the IL-23R rs11209026 polymorphism and UC. 
polymorphisms (except for rs10489629) are associated with UC risk. We also undertook subgroup analyses by ethnicity for these polymorphisms. Our findings provide strong evidence of a significant association between the IL23R polymorphisms, with the exception of the rs 1495965 and rs1343151 polymorphisms, and UC in Caucasians. The present study showed that the IL-23R rs1495965 and rs1343151 polymorphisms were not associated with UC in Caucasians and Asians. The reasons for this disagreement might arise from the followings. We found that the ORs (95\% CIs) of the individual studies [22, 24, $26]$ included in meta-analysis of rs 1343151 polymorphism were approximates to critical values (shown in Figure 6). If these studies increased the sample size, they might yield significant association. Similarly, ethnicity-specific analysis found that the IL-23R rs1004819 and rs11209032 polymorphisms were associated with UC susceptibility in Caucasians and Asians. However, polymorphisms studied, such as the rs11209026, rs7517847, rs 10889677 and rs2201841 polymorphisms, revealed a different association with UC between Caucasians and Asians.

The diverse roles of the same gene polymorphism in subgroup analysis by ethnicity could be ascribed to the followings. It is well known that UC is the most prevalent in North America and Europe, and the least prevalent among African Americans and Asians [56].
There is a susceptibility factor for UC in Caucasians, but not in Asians. It suggested that IL-23R gene might have a susceptibility nature in the Caucasians, while it was not suggested to have such a nature in the Asians. In addition, the two polymorphisms were found to confer susceptibility to both the populations, but the number of individual studies included and sample size of pooled data in Asians in the current meta-analysis were small, increasing the sample size might change the results, so the conclusions drawn from this limited number of study subjects might not look necessarily reliable.

With regard to the functional effects of IL-23R polymorphisms, rs10889677, a variant located in the 3'-untranslated region of the IL-23R gene, have been demonstrated to induce the loss of microRNA regulation and enhance the IL-23R mRNA levels and protein production. In combination with this variant (rs10889677), miRNA-mediated dysregulation of IL-23 signaling strongly associated with UC susceptibility [57]. Furthermore, rs10889677 SNP also can change the function of its receptor by promoting its overexpression, skewing $\mathrm{T}$ cells to differentiate towards Th17 leading to inflammation by increasing release of other cytokines [58]. Another intronic polymorphism Arg381Gln (rs11209026), located in 3'-region of exon 9 of IL-23R, is significantly associated with UC susceptibility. Yu et al. found the protective allele

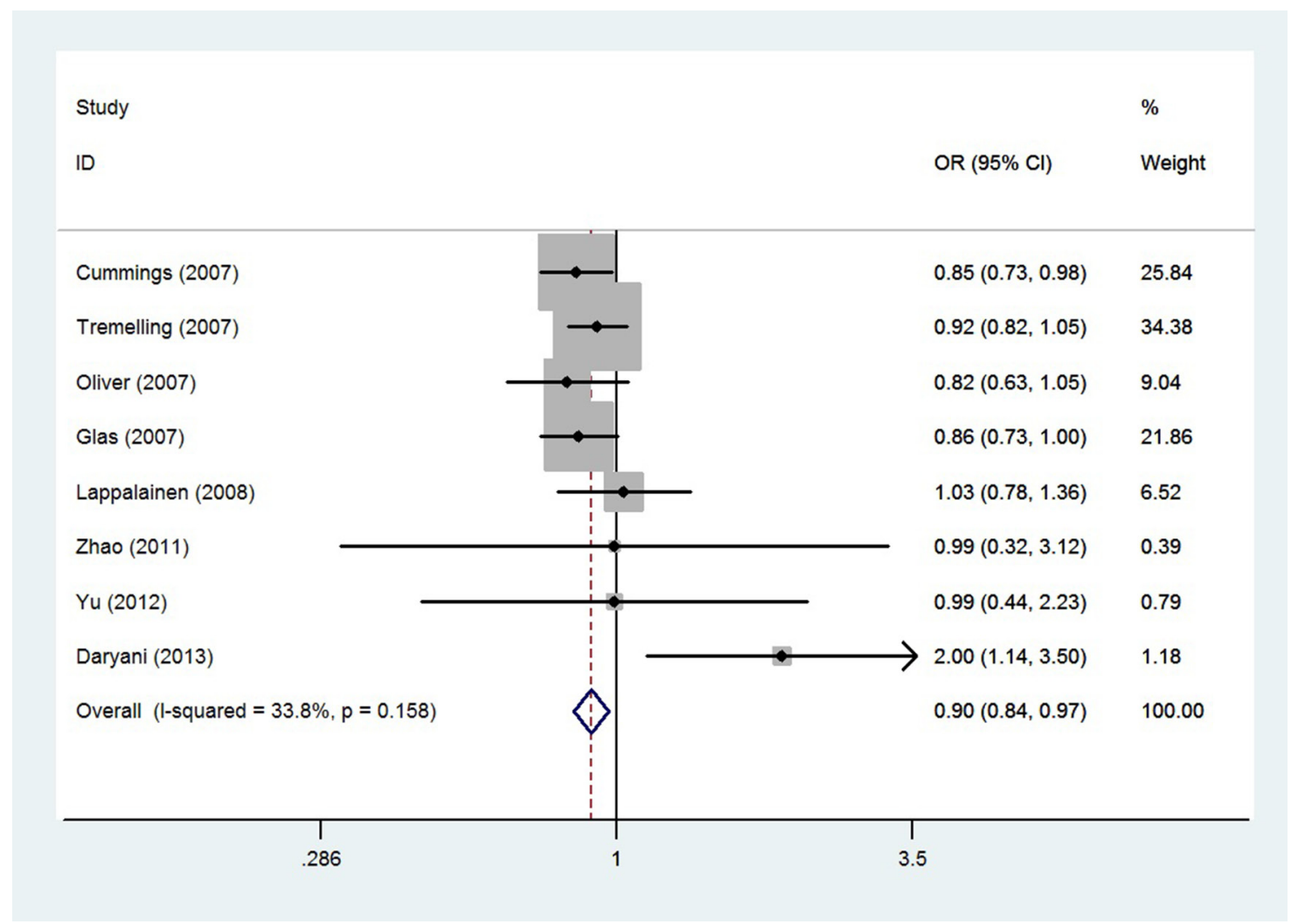

Figure 6: Odds ratios and $95 \%$ confidence intervals for individual studies and pooled data for the association between the $T$ versus $C$ allele of the IL-23R rs1343151 polymorphism and UC. 
A of rs11209026 SNP could increase the expression of the soluble form of IL-23R mRNA and diminish the induction of Th17 cells upon IL-23 stimulation [59].

The strength of our meta-analysis could be summarized as the followings. We did our best to identify as many published articles as we could through various searching approaches. Compared with the previous metaanalysis [53], the current study involved a total of 32 articles, which is much larger than the data from the previous metaanalysis. Thus, results of current study are more reliable, showing that IL-23R might be a potential therapeutic target for UC in combination with findings of GWAS studies and immnochip data. In addition, Jurgens et al. has examined the association of the IL-23R gene polymorphisms as a genetic predictor of infliximab responsiveness in UC patients and showed that UC patients carrying the IBD risk-increasing IL-23R polymorphisms were more likely to respond to infliximab than patients carrying the IBD risk-decreasing IL-23R polymorphisms $(74.1 \%$ vs. $34.6 \%, P=0.001)$, which suggests that IL-23R gene is related to treatment of UC patient [60]. Therefore, further research, involving larger and more diverse UC populations, are necessary in future, which in turn could lead to more accurate diagnosis and ultimately to the development of better drugs and more effective therapeutic strategies. Moreover, we performed subgroup analyses by ethnicity to look at the ethnic effect on the risk of UC. Besides, the "trim and fill" method was used to adjust for publication bias.

Certainly, some limitations of the present study should be addressed. First, this study could not analyze the potential gene-environment interactions and gene susceptibility haplotypes due to insufficient data. Second, our literature search was only limited on English and Chinese, language bias might exist. Third, significant between-study heterogeneity and publication bias was found in some analyses, which might have an influence on the current study. Fourth, some results are still controversial owing to relatively small sample size in Asians, and the results of meta-analysis were applicable only to the Asian and Caucasian groups.

In summary, the current study provides a comprehensive examination of the available evidence for the association between polymorphisms in the IL-23R gene and UC. The meta-analysis suggests that IL-23R gene polymorphisms are associated with UC susceptibility, especially in Caucasians. However, larger sample size studies taking environmental risk factor into account and including other ethnic groups are need to confirm the results from our meta-analysis in the future.

\section{MATERIALS AND METHODS}

\section{Publication research}

A systematic literature search in PubMed database, Elsevier Science Direct, China National Knowledge
Infrastructure database (CNKI), Wanfang Database, and Chinese Biomedical database (CBM) was carried out to identify potential articles and references in the identified articles were checked manually to find additional studies concerning the association between polymorphisms in the IL-23R gene and UC risk. The text words were as follows: "ulcerative colitis or inflammatory bowel disease or UC or IBD" and "Interleukin-23 receptor or IL-23R or IL23R" combined with "gene or polymorphism or variant". The languages were limited to English and Chinese. The last search was updated on May 1, 2016.

\section{Inclusion and exclusion criteria}

A study was included in the analysis if a) it was a case-control or cohort study; b) it included original data (independence among studies); c) the studies tested the association between the IL-23R gene polymorphisms (rs11209026, rs7517847, rs1004819, rs10889677, rs2201841, rs11209032, rs1495965, rs1343151, rs10489629, rs11465804) and UC risk, and d) the studies provided sufficient data to calculate the statistical indicators. Studies were excluded if one of the followings existed: a) studies contained overlapping data; b) studies in which family members had been studied because of the analysis based on linkage considerations.

\section{Data extraction}

The following data were extracted independently by two authors from each eligible article: first author's last name, publication year, population, ethnicity, numbers of cases and controls, genotyping methods, polymorphisms in the IL-23R gene studied and Hardy-Weinberg equilibrium (HWE) $P$-value.

\section{Statistical analysis}

Allele frequencies at the IL-23R gene polymorphisms from each single study were determined by the counting method. The pooled odds ratios (ORs) and $95 \%$ confidence intervals (CIs) were calculated to assess the strength of association between these gene polymorphisms and UC susceptibility. HWE was examined using the $\chi^{2}$ test.

The $\chi^{2}$-test based on the Q statistic was applied to examine the heterogeneity of between-study [61]. If $I^{2}$ was more than $50 \%$ and $P$ value was less than 0.1 , the heterogeneity was considered to be significant, and then the random effects model was selected for meta-analysis. Otherwise, a fixed effects model was adopted.

Publication bias was estimated by Egger's linear regression test and the Funnel plot. If the $P$ value was less than 0.05 , statistically significant publication bias might exist [62].

All the statistical analyses of meta-analysis were performed by STATA statistical software (version 11.0 
STATA Corp LP, College Station, TX, USA). A two-sided $P$ value $<0.05$ was regarded as statistically significant.

\section{Abbreviations}

GWAS: genome-wide association study; HLA: human leucocyte antigen; TNF- $\alpha$ : tumor necrosis factor; SNP: single nucleotide polymorphism; UC: ulcerative colitis; IL-23R: interleukin-23 receptor; JAK: Janus kinase; STAT: signal transducer and activator of transcription; AS: ankylosing spondylitis; RA: rheumatoid arthritis; IBD: inflammation bowel disease; CTLA-4: Cytotoxic T lymphocyte associated antigen-4; HWE: Hardy-Weinberg Equilibrium; OR: odds ratio; CI: confidence interval; CNKI: China National Knowledge Infrastructure database; CBM: Chinese Biomedical database.

\section{ACKNOWLEDGMENTS}

We would like to thank Dr. Hai-Feng Pan for performing linkage disequilibrium analysis.

\section{CONFLICTS OF INTEREST} interests.

The authors declare that they have no competing

\section{FUNDING}

This work was partly supported by grants from the ninth program of industry-techno innovation of Suzhou, 2015 (SYS201579).

\section{Author contributions}

X.L. Ji and J. Ni designed the study. L.L. Peng, F.L. Zhu and X.L. Ji did the systematic literature search and extracted the data. Y. Wang, W.D. Xu and J. Ni performed the statistical analysis and made all forms in the manuscript. L.L. Peng wote the manuscript, and all contributed to and approved the final version of the manuscript.

\section{REFERENCES}

1. Abraham $\mathrm{C}, \mathrm{Cho} \mathrm{JH}$. Inflammatory bowel disease. N Engl J Med. 2009; 361:2066-2078.

2. Zhang M, Ni J, Xu WD, Wen PF, Qiu LJ, Wang XS, Pan HF, Ye DQ. Association of CTLA-4 variants with susceptibility to inflammatory bowel disease: a meta-analysis. Hum Immunol. 2014; 75:227-233.

3. Zhang H, Massey D, Tremelling M, Parkes M. Genetics of inflammatory bowel disease: clues to pathogenesis. Br Med Bull. 2008; 87:17-30.
4. Cho JH, Brant SR. Recent insights into the genetics of inflammatory bowel disease. Gastroenterology. 2011; 140:1704-12.

5. Juyal G, Negi S, Sood A, Gupta A, Prasad P, Senapati S, Zaneveld J, Singh S, Midha V, van Sommeren S, Weersma RK, Ott J, Jain S, et al. Genome-wide association scan in north Indians reveals three novel HLA-independent risk loci for ulcerative colitis. Gut. 2015; 64:571-579.

6. Julià A, Domènech E, Chaparro M, García-Sánchez V, García-Sánchez V, Gomollón F, Panés J, Mañosa M, Barreiro-De Acosta M, Gutiérrez A, Garcia-Planella E, Aguas M, Muñoz F, Esteve M, Mendoza JL, et al. A genome-wide association study identifies a novel locus at 6q22.1 associated with ulcerative colitis. Hum Mol Genet. 2014; 23:6927-6934.

7. Jostins L, Ripke S, Weersma RK, Duerr RH, McGovern DP, Hui KY, Lee JC, Schumm LP, Sharma Y, Anderson CA, Essers J, Mitrovic M, Ning K, et al. Host-microbe interactions have shaped the genetic architecture of inflammatory bowel disease. Nature. 2012; 491:119-124.

8. Wellcome Trust Case Control Consortium. Genome-wide association study of 14,000 cases of seven common diseases and 3,000 shared controls. Nature. 2007; 447:661-678.

9. Anderson CA, Boucher G, Lees CW, Franke A, D'Amato M, Taylor KD, Lee JC, Goyette P, Imielinski M, Latiano A, Lagacé C, Scott R, Amininejad L, et al. Meta-analysis identifies 29 additional ulcerative colitis risk loci, increasing the number of confirmed associations to 47 . Nat Genet. $2011 ; 43: 246-252$.

10. Murphy CA, Langrish CL, Chen Y, Blumenschein W, McClanahan T, Kastelein RA, Sedgwick JD, Cua DJ, et al. Divergent pro- and antiinflammatory roles for IL-23 and IL-12 in joint autoimmune inflammation. J Exp Med. 2003; 198:1951-1957.

11. Yen D, Cheung J, Scheerens H, Poulet F, McClanahan T, McKenzie B, Kleinschek MA, Owyang A, Mattson J, Blumenschein W, Murphy E, Sathe M, Cua DJ, et al. IL-23 is essential for T cell-mediated colitis and promotes inflammation via IL-17 and IL-6. J Clin Invest. 2006; 116:1310-1316.

12. Parham C, Chirica M, Timans J, Vaisberg E, Travis M, Cheung J, Pflanz S, Zhang R, Singh KP, Vega F, To W, Wagner J, O'Farrell AM, et al. A receptor for the heterodimeric cytokine IL-23 is composed of IL-12Rbeta1 and a novel cytokine receptor subunit, IL-23R. J Immunol. 2002; 168:5699-5708.

13. Cho ML, Kang JW, Moon YM, Nam HJ, Jhun JY, Heo SB, Jin HT, Min SY, Ju JH, Park KS, Cho YG, Yoon CH, Park $\mathrm{SH}$, et al. STAT3 and NF-kappaB signal pathway is required for IL-23-mediated IL-17 production in spontaneous arthritis animal model IL-1 receptor antagonist-deficient mice. J Immunol. 2006; 176:5652-5661.

14. Kenna TJ, Davidson SI, Duan R, Bradbury LA, McFarlane J, Smith M, Weedon H, Street S, Thomas R, Thomas GP, Brown MA. Enrichment of circulating 
interleukin-17-secreting interleukin-23 receptor-positive $\gamma / \delta \mathrm{T}$ cells in patients with active ankylosing spondylitis. Arthritis Rheum. 2012; 64:1420-1429.

15. Petermann F, Rothhammer V, Claussen MC, Haas JD, Blanco LR, Heink S, Prinz I, Hemmer B, Kuchroo VK, Oukka M, Korn T. $\gamma / \delta$ T cells enhance autoimmunity by restraining regulatory $\mathrm{T}$ cell responses via an interleukin23-dependent mechanism. Immunity. 2010; 33:351-363.

16. Xavier RJ, Podolsky DK. Unravelling the pathogenesis of inflammatory bowel disease. Nature. 2007; 448:427-434.

17. Izcue $\mathrm{A}$, Hue $\mathrm{S}$, Buonocore $\mathrm{S}$, Arancibia-Cárcamo $\mathrm{CV}$, Ahern PP, Iwakura Y, Maloy KJ, Powrie F. Interleukin-23 restrains regulatory $\mathrm{T}$ cell activity to drive $\mathrm{T}$ cell-dependent colitis. Immunity. 2008; 28:559-570.

18. Song L, Zhou R, Huang S, Zhou F, Xu S, Wang W, Yi F, Wang X, Xia B. High intestinal and systemic levels of interleukin-23/T-helper 17 pathway in Chinese patients with inflammatory bowel disease. Mediators Inflamm. 2013; 2013:425915.

19. Duerr RH, Taylor KD, Brant SR, Rioux JD, Silverberg MS, Daly MJ, Steinhart AH, Abraham C, Regueiro M, Griffiths A, Dassopoulos T, Bitton A, Yang H, Targan S, et al. A genome-wide association study identifies IL23R as an inflammatory bowel disease gene. Science. 2006; 314:1461-1463.

20. Büning C, Schmidt HH, Molnar T, De Jong DJ, Fiedler T, Bühner S, Sturm A, Baumgart DC, Nagy F, Lonovics J, Drenth JP, Landt O, Nickel R, et al. Heterozygosity for IL23R p.Arg381Gln confers a protective effect not only against Crohn's disease but also ulcerative colitis. Aliment Pharmacol Ther. 2007; 26:1025-1033.

21. Cummings JR, Ahmad T, Geremia A, Beckly J, Cooney R, Hancock L, Pathan S, Guo C, Cardon LR, Jewell DP. Contribution of the novel inflammatory bowel disease gene IL23R to disease susceptibility and phenotype. Inflamm Bowel Dis. 2007; 13:1063-1068.

22. Glas J, Seiderer J, Wetzke M, Konrad A, Török HP, Schmechel S, Tonenchi L, Grassl C, Dambacher J, Pfennig S, Maier K, Griga T, Klein W, et al. rs1004819 is the main disease-associated IL23R variant in German Crohn's disease patients: combined analysis of IL23R, CARD15, and OCTN1/2 variants. PLoS One. 2007; 2:e819.

23. Van Limbergen J, Russell RK, Nimmo ER, Drummond HE, Smith L, Davies G, Anderson NH, Gillett PM, McGrogan P, Hassan K, Weaver L, Bisset WM, Mahdi G, et al. IL23R Arg381Gln is associated with childhood onset inflammatory bowel disease in Scotland. Gut. 2007; 56:1173-1174.

24. Oliver J, Rueda B, López-Nevot MA, Gómez-García M, Martín J. Replication of an association between IL23R gene polymorphism with inflammatory bowel disease. Clin Gastroenterol Hepatol. 2007; 5:977-981, 981.e1-2.

25. Roberts RL, Gearry RB, Hollis-Moffatt JE, Miller AL, Reid J, Abkevich V, Timms KM, Gutin A, Lanchbury JS, Merriman TR, Barclay ML, Kennedy MA. IL23R
R381Q and ATG16L1 T300A are strongly associated with Crohn's disease in a study of New Zealand Caucasians with inflammatory bowel disease. Am J Gastroenterol. 2007; 102:2754-2761.

26. Tremelling M, Cummings F, Fisher SA, Mansfield J, Gwilliam R, Keniry A, Nimmo ER, Drummond $\mathrm{H}$, Onnie CM, Prescott NJ, Sanderson J, Bredin F, Berzuini $\mathrm{C}$, et al. IL23R variation determines susceptibility but not disease phenotype in inflammatory bowel disease. Gastroenterology. 2007; 132:1657-1664.

27. Lakatos PL, Szamosi T, Szilvasi A, Molnar E, Lakatos L, Kovacs A, Molnar T, Altorjay I, Papp M, Tulassay Z, Miheller P, Papp J, Tordai A, et al. ATG16L1 and IL23 receptor (IL23R) genes are associated with disease susceptibility in Hungarian CD patients. Dig Liver Dis. 2008; 40:867-873.

28. Lappalainen M, Halme L, Turunen U, Saavalainen P, Einarsdottir E, Färkkilä M, Kontula K, Paavola-Sakki P. Association of IL23R, TNFRSF1A, and HLA-DRB1*0103 allele variants with inflammatory bowel disease phenotypes in the Finnish population. Inflamm Bowel Dis. 2008; 14:1118-1124.

29. Latiano A, Palmieri O, Valvano MR, D'Incà R, Cucchiara S, Riegler G, Staiano AM, Ardizzone S, Accomando S, de Angelis GL, Corritore G, Bossa F, Annese V. Replication of interleukin 23 receptor and autophagy-related 16-like 1 association in adult- and pediatric-onset inflammatory bowel disease in Italy. World J Gastroenterol. 2008; 14:4643-4651.

30. Lu ZK, Chen ZR, Zheng JJ, Shi RH. Association study of IL-23R Arg381Gln polymorphism and inflammatory bowel disease. Chin J Dig. 2010; 30:782-784.

31. Márquez A, Mendoza JL, Taxonera C, Díaz-Rubio M, De La Concha EG, Urcelay E, Martínez A. IL23R and IL12B polymorphisms in Spanish IBD patients: no evidence of interaction. Inflamm Bowel Dis. 2008; 14:1192-1196.

32. Okazaki T, Wang MH, Rawsthorne P, Sargent M, Datta LW, Shugart YY, Bernstein CN, Brant SR. Contributions of IBD5, IL23R, ATG16L1, and NOD2 to Crohn's disease risk in a population-based case-control study: evidence of genegene interactions. Inflamm Bowel Dis. 2008; 14:1528-1541.

33. Venegas M, Beltrán CJ, Alvarez L, Castro A, Torres T, Leal AD, Lahsen FM, Hermoso MA, Quera R. IL-23R Arg381Gln polymorphism in Chilean patients with inflammatory bowel disease. Eur Cytokine Netw. 2008; 19:190-195.

34. Weersma RK, Zhernakova A, Nolte IM, Lefebvre C, Rioux JD, Mulder F, van Dullemen HM, Kleibeuker JH, Wijmenga C, Dijkstra G. ATG16L1 and IL23R are associated with inflammatory bowel diseases but not with celiac disease in the Netherlands. Am J Gastroenterol. 2008; 103:621-627.

35. Chen ZY, Zhi FC, Zhi J. Preliminary study on relationship between gene polymorphisms of interleukin-23 receptor and inflammatory bowel disease. Chin J Dig. 2008; 28:369-372. 
36. Weersma RK, Stokkers PC, Cleynen I, Wolfkamp SC, Henckaerts L, Schreiber S, Dijkstra G, Franke A, Nolte IM, Rutgeerts P, Wijmenga C, Vermeire S. Confirmation of multiple Crohn's disease susceptibility loci in a large DutchBelgian cohort. Am J Gastroenterol. 2009; 104:630-638.

37. Cotterill L, Payne D, Levinson S, McLaughlin J, Wesley E, Feeney M, Durbin H, Lal S, Makin A, Campbell S, Roberts SA, O'Neill C, Edwards C, et al. Replication and metaanalysis of 13,000 cases defines the risk for interleukin-23 receptor and autophagy-related 16-like 1 variants in Crohn's disease. Can J Gastroenterol. 2010; 24:297-302.

38. Lacher M, Schroepf S, Helmbrecht J, von Schweinitz D, Ballauff A, Koch I, Lohse P, Osterrieder S, Kappler R, Koletzko S. Association of the interleukin-23 receptor gene variant rs11209026 with Crohn's disease in German children. Acta Paediatr. 2010; 99:727-733.

39. Mahurkar S, Banerjee R, Rani VS, Thakur N, Rao GV, Reddy DN, Chandak GR. Common variants in NOD2 and IL23R are not associated with inflammatory bowel disease in Indians. J Gastroenterol Hepatol. 2011; 26:694-699.

40. Mitrovič M, Potočnik U. High Resolution Melting Curve Analysis for High-Throughput SNP Genotyping in IL23R Gene and Association of IL23R with Slovenian Inflammatory Bowel Diseases Patients. Acta Chim Slov. 2010; 57:498-505.

41. Sventoraityte J, Zvirbliene A, Franke A, Kwiatkowski R, Kiudelis G, Kupcinskas L, Schreiber S. NOD2, IL23R and ATG16L1 polymorphisms in Lithuanian patients with inflammatory bowel disease. World J Gastroenterol. 2010; 16:359-364.

42. Yang SK, Jung Y, Hong M, Kim H, Ye BD, Lee I, Song K. No association between TNFSF15 and IL23R with ulcerative colitis in Koreans. J Hum Genet. 2011; 56:200-204.

43. Zhao XD, Shen FC, Zhang HJ, Shen XY, Wang YM, Yang XZ, Tu HM, Tai YH, Shi RH. Association of interleukin-23 receptor gene polymorphisms with susceptibility and phenotypes of inflammatory bowel diseases in Jiangsu Han population. Chinese Journal of Internal Medicine. 2011; 50:935-941.

44. Hayatbakhsh MM, Zahedi MJ, Shafiepour M, Nikpoor AR, Mohammadi M. IL-23 receptor gene rs7517847 and rs 1004819 SNPs in ulcerative colitis. Iran J Immunol. 2012; 9:128-135.

45. Safrany E, Szabo M, Szell M, Kemeny L, Sumegi K, Melegh BI, Magyari L, Matyas P, Figler M, Weber A, Tulassay Z, Melegh B. Difference of interleukin-23 receptor gene haplotype variants in ulcerative colitis compared to Crohn's disease and psoriasis. Inflamm Res. 2013; 62:195-200

46. Kanaan ZM, Eichenberger MR, Ahmad S, Weller C, Roberts H, Pan J, Rai SN, Petras R, Weller EB Jr, Galandiuk S. Clinical predictors of inflammatory bowel disease in a genetically well-defined Caucasian population. J Negat Results Biomed. 2012; 11:7.
47. Yu P, Shen F, Zhang X, Cao R, Zhao X, Liu P, Tu H, Yang X, Shi R, Zhang H. Association of single nucleotide polymorphisms of IL23R and IL17 with ulcerative colitis risk in a Chinese Han population. PLoS One. 2012; 7:e44380.

48. Ebrahimi Daryani N, Najmi Varzaneh F, Hedayat M, Taher M, Farhadi E, Mahmoudi M, Nicknam MH, Bashashati M, Rezaei N. Interleukin-23 receptor single nucleotide polymorphisms in ulcerative colitis. A study in Iranian populations. Clin Res Hepatol Gastroenterol. 2014; 38:360-365.

49. Mihaljević S, Kibel A, Stefanić M, Glavas-Obrovac L, Takac B, Krznarić Z, Samardiija M, Pinotić L, Milas J, Segec I. Polymorphisms of interleukin-23 receptor in patients with inflammatory bowel disease in a Croatian tertiary center. Coll Antropol. 2013; 37:1171-1177.

50. Skieceviciene J, Kiudelis G, Ellinghaus E, Balschun T, Jonaitis LV, Zvirbliene A, Denapiene G, Leja M, Pranculiene G, Kalibatas V, Saadati H, Ellinghaus D, Andersen V, et al. Replication study of ulcerative colitis risk loci in a Lithuanian-Latvian case-control sample. Inflamm Bowel Dis. 2013; 19:2349-2355.

51. Sarlos P, Varszegi D, Csongei V, Magyari L, Jaromi L, Nagy L, Melegh B. Susceptibility to ulcerative colitis in Hungarian patients determined by gene-gene interactions. World J Gastroenterol. 2014; 20:219-227.

52. Zhang C, Wang W, Zhang H, Wei L, Guo S. Association of FCGR2A rs1801274 polymorphism with susceptibility to autoimmune diseases: A meta-analysis. Oncotarget. 2016; 7:39436-39443. doi: 10.18632/oncotarget.9831.

53. Liu M, Zhu W, Wang J, Zhang J, Guo X, Wang J, Song J, Dong W. Interleukin-23 receptor genetic polymorphisms and ulcerative colitis susceptibility: A meta-analysis. Clin Res Hepatol Gastroenterol. 2015; 39:516-525.

54. Bouma G, Strober W. The immunological and genetic basis of inflammatory bowel disease. Nat Rev Immunol. 2003; 3:521-533.

55. Abdollahi E, Tavasolian F, Momtazi-Borojeni AA, Samadi M, Rafatpanah H. Protective role of R381Q (rs11209026) polymorphism in IL-23R gene in immune-mediateddiseases: A comprehensive review. J Immunotoxicol. 2016; 13:286-300.

56. Cho JH. Inflammatory bowel disease: genetic and epidemiologic considerations. World J Gastroenterol. 2008; 14:338-347.

57. Zwiers A, Kraal L, van de Pouw Kraan TC, Wurdinger T, Bouma G, Kraal G. Cutting edge: a variant of the IL-23R gene associated with inflammatory bowel disease induces loss of microRNA regulation and enhanced protein production. J Immunol. 2012; 188:1573-1577.

58. Safrany E, Melegh B. Functional variants of the interleukin-23 receptor Gene in non-gastrointestinal autoimmune diseases. Curr Med Chem. 2009; 16:3766-3774. 
59. Yu RY, Brazaitis J, Gallagher G. The human IL-23 rece ptor rs11209026 A allele promotes the expression of a soluble IL-23R-encodingmRNA species. J Immunol. 2015; 194:1062-1068.

60. Jürgens M, Laubender RP, Hartl F, Weidinger M, Seiderer J, Wagner J, Wetzke M, Beigel F, Pfennig S, Stallhofer J, Schnitzler F, Tillack C, Lohse P, et al. Disease activity, ANCA, and IL23R genotype status determine early response to infliximab in patients with ulcerative colitis. Am J Gastroenterol. 2010; 105:1811-1819.

61. Higgins JP, Thompson SG. Quantifying heterogeneity in a meta-analysis. Stat Med. 2002; 21:1539-1558.

62. Egger M, Davey Smith G, Schneider M, Minder C. Bias in meta-analysis detected by a simple, graphical test. BMJ. 1997; 315:629-634. 